\title{
ANALISIS KOMPARASI KINERJA KEUANGANBANK SYARIAH DAN BANK KONVENSIONAL DENGAN PENDEKATAN CAMEL PADA PT BANK BNI SYARIAH, TBK dan PT BANK BNI, TBK PERIODE 2014-2018
}

\author{
Monica Olivia \\ Institut Agama Islam Negeri Pontianak \\ Email : monica_olivia@iainptk.ac.id
}

\begin{abstract}
This study aims to examine the comparison of the financial performance of bni syariah banks and conventional bni banks using the CAMEL method, in the period 2014-2018. The method used in this study is a descriptive research method, with a quantitative approach. The type of data used is secondary data, in the form of company financial statements. The test was carried out using the Independent Sample T-Test method using the SPSS 20 program. The results of this study indicate that car and fdr/ldr are not significant differences, but npf/npl, bopo and roa are significant differences between bni syariah banks and conventional bni banks.
\end{abstract}

Keywords : Bank BNI Syariah, Conventional BNI Bank, CAMEL, CAR, FDR/LDR, NPF/NPL/BOPO, ROA 


\section{PENDAHULUAN}

Dunia perbankan di Indonesia kini diramaikan dengan adanya bank syariah. Negara yang mayoritas penduduknya beragama Islam ini merupakan lahan yang subur untuk perkembangan industri jasa yang menggunakan hukum dan landasan Islam dalam praktek usahanya. Beberapa faktor yang mendukung didirikannya perbankan syariah adalah tingkat religiusitas, kemajuan teknologi, dan tuntutan nasabah. Selain itu perbedaan karakteristik perbankan syariah dengan perbankan konvensional membuat kompetisi antar kedua jenis bank ini semakin ketat.

Dalam sudut pandang Islam, sistem yang berlaku di Bank Konvensional adalah riba. Dalam hal ini, riba adalah sebuah sistem yang dilarang dalam Islam sehingga sistem Bank Konvensional tersebut dianggap tidak sejalan dengan orientasi Islam dalam hal perbankan. Berikut tabel perbedaan antara bank syariah dan bank konvensional:

Tabel 1.1

\section{Perbedaan Bank Syariah dan Bank Konvensional}

\begin{tabular}{|l|l|l|l|}
\hline NO & KETERANGAN & BANK SYARIAH & BANK KONVENSIONAL \\
\hline 1 & Falsafah & $\begin{array}{l}\text { Tidak berdasarkan bunga, } \\
\text { spekulasi, dan } \\
\text { ketidakjelasan. }\end{array}$ & Berdasarkan bunga. \\
\hline 2 & Operasional & $\begin{array}{l}\text { Dana masyarakat berupa } \\
\text { titipan dan investasi yang } \\
\text { baru akan mendapatkan } \\
\text { hasil jika "diusahakan" } \\
\text { terlebih dahulu. } \\
\text { Penyaluran pada usaha yang } \\
\text { halal dan menguntungkan }\end{array}$ & $\begin{array}{l}\text { Dana masyarakat berupa } \\
\text { simpanan yang harus dibayar } \\
\text { bunganya pada saat jatuh } \\
\text { tempo. } \\
\text { Penyaluran pada sektor yang } \\
\text { menguntungkan aspek halal } \\
\text { tidak menjadi pertimbangan } \\
\text { utama. }\end{array}$ \\
\hline 3 & Aspek Sosial & $\begin{array}{l}\text { Dinyatakan secara eksplisit } \\
\text { dan tegas yang tertuang } \\
\text { dalam misi dan visi }\end{array}$ & $\begin{array}{l}\text { Tidak diketahui secara tegas } \\
\text { Harus memiliki Dewan } \\
\text { Pengawas Syariah }\end{array}$ \\
\hline 4 & Organisasi & $\begin{array}{l}\text { Tidak memiliki Dewan } \\
\text { Pengawas Syariah }\end{array}$ \\
\hline
\end{tabular}

Sumber: IBI, 2002. (Dalam Sudarsono, Heri. 2013. Bank dan Lembaga Keuangan Syariah: Ekonisia)

Tabel 1.1 diatas memaparkan beberapa perbedaan antara bank syariah dan bank konvensional, sehingga merubah pandangan beberapa kelompok ma syarakat di Indonesia untuk beralih menjadi nasabah bank syariah. Beberapa faktor tersebut menyebabkan 
bank-bank konvensional di Indonesia kini mengikuti tren dengan mendirikan unit usaha syariah dan bank umum syariah. Hal inilah yang mendorong PT Bank BNI, Tbk melirik dunia usaha syariah sebagai ide untuk menarik nasabah dengan fitur - fitur yang berlandaskan prinsip syariah sehingga mendirikan PT BNI Syariah, Tbk. Berdasarkan Keputusan Gubernur Bank Indonesia Nomor 12/41/KEP.GBI/2010 tanggal 21 Mei 2010 mengenai pemberian izin usaha kepada PT Bank BNI Syariah dan di dalam Corporate Plan UUS BNI tahun 2003 ditetapkan bahwa status UUS bersifat temporer dan akan dilakukan spin off tahun 2009. Rencana tersebut terlaksana pada tanggal 19 Juni 2010 dengan beroperasinya BNI Syariah sebagai Bank Umum Syariah (BUS). Realisasi waktu spin off bulan Juni 2010 tidak terlepas dari faktor eksternal berupa aspek regulasi yang kondusif yaitu dengan diterbitkannya UU No.19 tahun 2008 tentang Surat Berharga Syariah Negara (SBSN) dan UU No.21 tahun 2008 tentang Perbankan Syariah.

Komitmen Pemerintah terhadap pengembangan perbankan syariah semakin kuat dan kesadaran terhadap keunggulan produk perbankan syariah juga semakin meningkat. Untuk itu, baik perbankan syariah maupun perbankan konvensional harus mampu menjaga tingkat kesehatan kinerja keuangannya secara optimal, agar dapat mempertahankan konsistensinya di masa depan. Salah satu metode untuk mengukur tingkat kesehatan Bank Syariah dan Konvensional salah satunya menggunakan pendekatan Peraturan Bank Indonesia No. 9/1/PBI/2007. Unsur -unsur yang harus ada dalam penilaian ini adalah kecukupan modal (Capital), kualitas aset (Assets), kualitas manajemen (Management), rentabilitas (Earnings), likuiditas (Liquidity), sensitifitas terhadap risiko pasar (Sensitivity to Market Risk). Penilaian tingkat kesehatan ini disebut juga dengan metode CAMELS (Darmawi, 2011). Berikut tabel rasio keuang an pada PT Bank BNI Syariah, Tbk d an PT Bank BNI, Tbk:

\section{Tabel 1.2}

\begin{tabular}{|l|c|c|c|c|c|c|c|c|c|c|}
\hline \multirow{2}{*}{$\begin{array}{c}\text { RASIO } \\
\boldsymbol{\%}\end{array}$} & \multicolumn{4}{|c|}{ BANK BNI SYARIAH } & \multicolumn{5}{c|}{ BANK BNI KONVENSIONAL } \\
\cline { 2 - 11 } & $\mathbf{2 0 1 4}$ & $\mathbf{2 0 1 5}$ & $\mathbf{2 0 1 6}$ & $\mathbf{2 0 1 7}$ & $\mathbf{2 0 1 8}$ & $\mathbf{2 0 1 4}$ & $\mathbf{2 0 1 5}$ & $\mathbf{2 0 1 6}$ & $\mathbf{2 0 1 7}$ & $\mathbf{2 0 1 8}$ \\
\hline CAR & 0.18 & 0.15 & 0.14 & 0.20 & 0.19 & 0.24 & 0.19 & 0.19 & 0.18 & 0.18 \\
\hline NPF/NPL & 1.04 & 1.46 & 1.64 & 1.50 & 1.52 & 0.39 & 0.91 & 0.44 & 0.70 & 0.85 \\
\hline
\end{tabular}




\begin{tabular}{|l|c|c|c|c|c|c|c|c|c|c|} 
BOPO & 89.80 & 89.63 & 87.67 & 87.62 & 85.37 & 68.02 & 75.48 & 73.59 & 70.99 & 70.15 \\
\hline ROA & 1.27 & 1.43 & 1.44 & 1.31 & 1.42 & 3.49 & 2.64 & 2.69 & 2.75 & 2.78 \\
\hline FDR/LDR & 92.60 & 91.94 & 84.57 & 80.21 & 79.62 & 87.81 & 87.77 & 90.41 & 85.58 & 88.76 \\
\hline
\end{tabular}

Rasio Kinerja Keuangan Periode 2014 - 2018

Sumber: Data diolah, 2019.

Berdasarkan Tabel 1.2 diatas dapat dilihat bahwa baik perbankan syariah maupun perbankan konvensional mengalami dinamika (naik-turun) pertumbuhan usahanya yang tercermin di dalam rasio kinerja keuangan setiap tahunnya. Oleh karena itu, peneliti tertarik untuk mengangkat tema "Analisis Komparasi Kinerja Keuangan dengan Pendekatan CAMEL pada PT Bank BNI Syariah, Tbk dan PT Bank BNI, Tbk periode 2014 - 2018". Untuk menjawab pertanyaan apakah ada perbedaan yang signifikan terhadap rasio-rasio kinerja keuangan antara PT Bank BNI Syariah dan PT Bank BNI Konvensional dengan menggunakan metode CAMEL.

\section{KAJIAN TEORI}

\section{Bank}

Kasmir (2009:25) memberikan pengertian bank sebagai berikut: "Department of store, yang merupakan organisasi jasa atau pelayanan berbagai macam jasa keuangan. Bank dikenal sebagai lembaga keuangan yang kegiatan utamanya menerima simpanan giro, tabungan dan deposito. Bank juga dikenal sebagai tempat untuk meminjam uang atau kredit bagi masyarakat yang membutuhkannya. Disamping itu, bank juga dikenal sebagai tempat untuk menukar uang, atau menerima segala macam bentuk pembayaran dan setoran."

Sedangkan menurut Undang-undang No. 7 Tahun 1992 tentang Perbankan diperbaharui dengan Undang-undang No. 10 Tahun 1998, "Bank adalah badan usaha yang menghimpun dana dari masyarakat dalam bentuk simpanan dan menyalurkannya kepada masyarakat dalam bentuk kredit atau bentuk-bentuk lainnya dalam rangka meningkatkan taraf hidup rakyat banyak". Fungsi utama bank sebagai Financial Intermediary, yaitu suatu lembaga yang mempunyai peranan untuk mempertemukan antara pemilik dan pengguna data. Oleh sebab itu, kegiatan perbankan harus berjalan secara efisien pada skala makro maupun mikro. 
Sedangkan menurut Sudarsono, Heri. 2013 yang dimaksud dengan” bank syariah adalah lembaga keuangan yang usaha pokoknya memberikan kredit dan jasa-jasa lain dalam lalu lintas pembayaran serta peredaran uang yang beroperasi disesuaikan dengan prinsip-prinsip syariah".

\section{Tingkat Kesehatan Bank}

Kesehatan keuangan bank dapat diartikan sebagai kemampuan suatu bank untuk melakukan kegiatan operasional perbankan secara normal seperti kemampuan menghimpun dana dari masyarakat, dari lembaga lain, dan dari modal sendiri, kemampuan pengelola dana, kemampuan untuk menyalurkan dana ke masyarakat, karyawan, pemilik modal, dan pihak lain, pemenuhan peraturan perbankan yang berlaku dan mampu memenuhi semua kewajiban dengan baik dengan cara-cara yang sesuai dengan peraturan perbankan yang berlaku. (Sigit Triandaru dan Totok Budisantoso, 2006:51) .

Peraturan Otoritas Jasa Keuangan (POJK) Nomor 8/POJK.03/2014 tentang Penilaian Tingkat Kesehatan Bank Umum Syariah dan Unit Usaha Syariah disusun dalam rangka meningkatkan efektivitas penilaian tingkat kesehatan bank untuk menghadapi perubahan kompleksitas usaha dan profil risiko yang dapat berasal dari bank maupun dari perusahaan anak bank.

Hal mendasar yang membedakan antara lembaga keuangan konvensional dengan syariah adalah terletak pada pengembalian dan pembagian keuntungan yang diberikan oleh nasabah kepada lembaga keuangan atau yang diberikan oleh lembaga keuangan kepada nasabah. Hal inilah yang menyebabkan terdapatnya istilah bunga dan bagi hasil. Bagi hasil menurut terminologi asing (inggris) dikenal dengan profit sharing. Dalam kamus ekonomi diartikan dengan pembagian laba. Secara defenitif, profit sharing diartikan "distribusi beberapa bagian dari laba pada para pegawai di sebuah perusahaan" (Muhammad, 2005: 11). Islam mendorong praktik bagi hasil serta mengharamkan riba. Keduanya sama-sama memberi keuntungan bagi pemilik dana, namun keduanya mempunyai perbedan yang sangat nyata. 


\section{Kinerja Keuangan}

Kinerja keuangan merupakan gambaran kondisi keuangan perusahaan pada suatu periode tertentu menyangkut aspek penghimpunan dana maupun penyaluran dana, yang biasanya diukur dengan indikator kecukupan modal, likuiditas, dan profitabilitas (Jumingan, 2011). Secara sederhana dapat dikatakan bahwa bank yang sehat adalah bank yang dapat menjalankan fungsi-fungsinya dengan baik. Dengan kata lain, bank yang sehat adalah bank yang dapat menjaga dan memelihara kepercayaan masyarakat, dapat menjalankan fungsi intermediasi, dapat membantu kelancaran lalu lintas pembayaran serta dapat digunakan oleh pemerintah dalam melaksanakan berbagai kebijakannya, terutama kebijakan moneter.

Dengan menjalankan fungsi-fungsi tersebut diharapkan dapat memberikan pelayanan yang baik kepada masyarakat serta bermanfaat bagi perekonomian secara keseluruhan. Budisantoso dan Triandaru (2006:51) mengartikan kesehatan bank sebagai "kemampuan suatu bank untuk melakukan kegiatan operasional perbankan secara normal dan mampu memenuhi semua kewajibannya dengan baik dengan cara-cara yang sesuai dengan peraturan yang berlaku". Penilaian tingkat kesehatan bank di Indonesia sampai saat ini secara garis besar didasarkan pada faktor CAMEL (Capital, Assets Quality, Management, Earning dan Liquidity).

Kelima faktor tersebut memang merupakan faktor yang menentukan kondisi suatu bank. Penilaian kesehatan bank dengan metode CAMEL, dimulai dengan penghitungan rasio - rasio dari masing-masing faktor. Menurut Jacob, 2013 dalam menilai kesehatan bank terdiri dari lima aspek yaitu :

1. Capital ((Capital Adequacy Ratio),

2. Assets (Non Perfoming Loan),

3. Management ((Biaya Operasional Pendapatan Operasional),

4. Earnings (Return On Assets),

5. Liquidity (Loan to Deposit Ratio).

Berikut ini penjelasan dari kelima aspek dengan metode CAMEL di atas :

a. CAR (Capital Adequacy Ratio) 
Rasio CAR adalah kecukupan modal yang menunjukan kemampuan bank dalam merpertahankan modal yang mencukupi dan kemampuan manajemen dalam mengidentifikasi, mengukur, mengawasi, dan mengontrol risiko-risiko yang timbul yang dapat berpengaruh terhadap besarnya modal bank (Kuncoro dan Suhardjono, 2002). Rumus CAR sebagai berikut :

$C A R=\frac{\text { Total Modal }}{\text { ATMR }} \times 100 \%$

b. NPL (Non Perfoming Loan)

Merupakan rasio yang menunjukkan kemampuan manajemen bank dalam mengelola kredit bermasalah yang diberikan oleh bank. Kredit bermasalah yaitu suatu keadaan dimana nasabah sudah tidak sanggup membayar sebagian atau seluruh kewajibannya kepada bank seperti yang telah diperjanjikan. Setiap bank harus mampu mengelola kreditnya dengan baik dalam memberikan kredit kepada masyarakat maupun dalam pengembalian kreditnya sesuai dengan syarat dan ketentuan yang berlaku sehingga tidak menimbulkan kredit bermasalah (Ismail, 2009:224). Rumus NPL sebagai berikut :

NPL $=\frac{\text { Kredit Bermasalah }}{\text { Total Kredit }} \times 100 \%$

c. BOPO (Biaya Operasional Pendapatan Operasional)

Untuk mengukur tingkat efisensi kemampuan bank dalam melakukan kegiatan operasinya, semakin tinggi rasio ini menunjukan semakin tidak efisien biaya operasional bank (Kasmir, 2003:268). Rumus BOPO sebagai berikut :

$B O P O=\frac{\text { Biaya Operasional }}{\text { Pendapatan Operasional }} \times 100 \%$

d. ROA (Return On Assets)

ROA digunakan untuk mengukur kemampuan manajemen bank dalam memperoleh laba secara keseluruhan dari total aktiva yang dimiliki (Dendawijaya, 2009). Rumus ROA sebagai berikut : 


\section{$R O A=\frac{\text { Laba Sebelum Pajak }}{\text { Total Asset }} \times 100 \%$}

\section{e. LDR (Loan to Deposit Ratio)}

Digunakan untuk menilai likuiditas suatu bank dengan cara membagi jumlah kredit yang diberikan oleh bank terhadap dana pihak ketiga (Kasmir, 2003:270). Rumus LDR sebagai berikut:

$L D R=\frac{\text { Jumlah Kredit Pihak Ketiga }}{\text { Total Dana Pihak Ketiga }} \times 100 \%$

\section{METODOLOGI PENELITIAN}

Penelitian yang digunakan dalam penelitian ini adalah penelitian deskriptif kuantitatif dengan metode statistik parametrik uji beda rata-rata (t-test). Uji t merupakan jenis pengujian statistik untuk mengetahui apakah terdapat perbedaan nilai dari yang diperkirakan dengan nilai hasil perhitungan statistik. Syarat untuk melakukan uji t antara lain nilai parameter diketahui/ditentukan; dan distribusi normal. Uji yang digunakan dalam penelitian ini adalah independent-sample $t$ test. Independent sample $t$ test digunakan untuk mengetahui signifikansi beda rata-rata dua kelompok.

\section{HASIL PENELITIAN DAN PEMBAHASAN}

Analisis Perbandingan Kinerja Keuangan Bank Konvensional dan Bank Syariah Berdasarkan hasil pengujian hipotesis yang telah dilakukan dengan menggunakan SPSS versi 20, dengan asumsi:

Ho1 : Tidak terdapat perbedaan yang signifikan antara rata-rata CAR antara PT Bank BNI Syariah dengan PT Bank BNI Konvensional.

Ha1 : Terdapat perbedaan yang signifikan antara rata-rata CAR antara PT Bank BNI Syariah dengan PT Bank BNI Konvensional.

Ho2 : Tidak terdapat perbedaan yang signifikan antara rata-rata NPF/NPL antara PT Bank BNI Syariah dengan PT Bank BNI Konvensional.

Ha2 : Terdapat perbedaan yang signifikan antara rata-rata NPF/NPL antara PT Bank BNI Syariah dengan PT Bank BNI Konvensional. 
Ho3 : Tidak terdapat perbedaan yang signifikan antara rata-rata BOPO antara PT Bank BNI Syariah dengan PT Bank BNI Konvensional.

Ha3 : Terdapat perbedaan yang signifikan antara rata-rata BOPO antara PT Bank BNI Syariah dengan PT Bank BNI Konvensional.

Ho4 : Tidak terdapat perbedaan yang signifikan antara rata-rata ROA antara PT Bank BNI Syariah dengan PT Bank BNI Konvensional.

Ha4 : Terdapat perbedaan yang signifikan antara rata-rata ROA antara PT Bank BNI Syariah dengan PT Bank BNI Konvensional.

Ho5: Tidak terdapat perbedaan yang signifikan antara rata-rata FDR/LDR antara PT Bank BNI Syariah dengan PT Bank BNI Konvensional.

Ha5: Terdapat perbedaan yang signifikan antara rata-rata FDR/LDR antara PT Bank BNI Syariah dengan PT Bank BNI Konvensional.

Hasil uji Independent t-test menunjukkan bahwa tidak terdapat perbedaan yang signifikan terhadap rasio CAR dan FDR/LDR pada PT Bank BNI Konvensional dan PT Bank BNI Syariah. Hal ini didukung oleh penelitian yang telah dilakukan oleh Himyar Pasrizal dkk (2018) yang menyimpulkan bahwa bahwa tidak terdapat perbedaan signifikan antara kinerja keuangan Bank Umum Syariah dengan Bank Umum Konvensional berdasarkan Capital Adequeency Ratio (CAR). Sedangkan hasil penelitian Arie Firmansyah Saragih (2013) mendukung bahwa tidak terdapat perbedaan yang signifikan pada rasio FDR/LDR antara perbankan syariah terhadap perbankan konvensional periode 2008-2010.

Namun, hasil uji Independent t-test untuk rasio NPF/NPL, BOPO dan ROA pada PT Bank BNI Konvensional dan PT Bank BNI Syariah diketahui bahwa terdapat perbedaan yang signifikan. Hasil penelitian ini sama dengan hasil penelitian yang dilakukan oleh Tria Hermawati. dkk (2018) yang menyimpulkan bahwa terdapat perbedaan signifikan terhadap rasio kinerja keuangan NPF/NPL, BOPO dan ROA antara Bank Mandiri Konvensional dengan Bank Syariah Mandiri. Berikut pembahasan hasil uji SPSS 20 pada penelitian ini: 
Tabel 4.1

Independent Samples Test

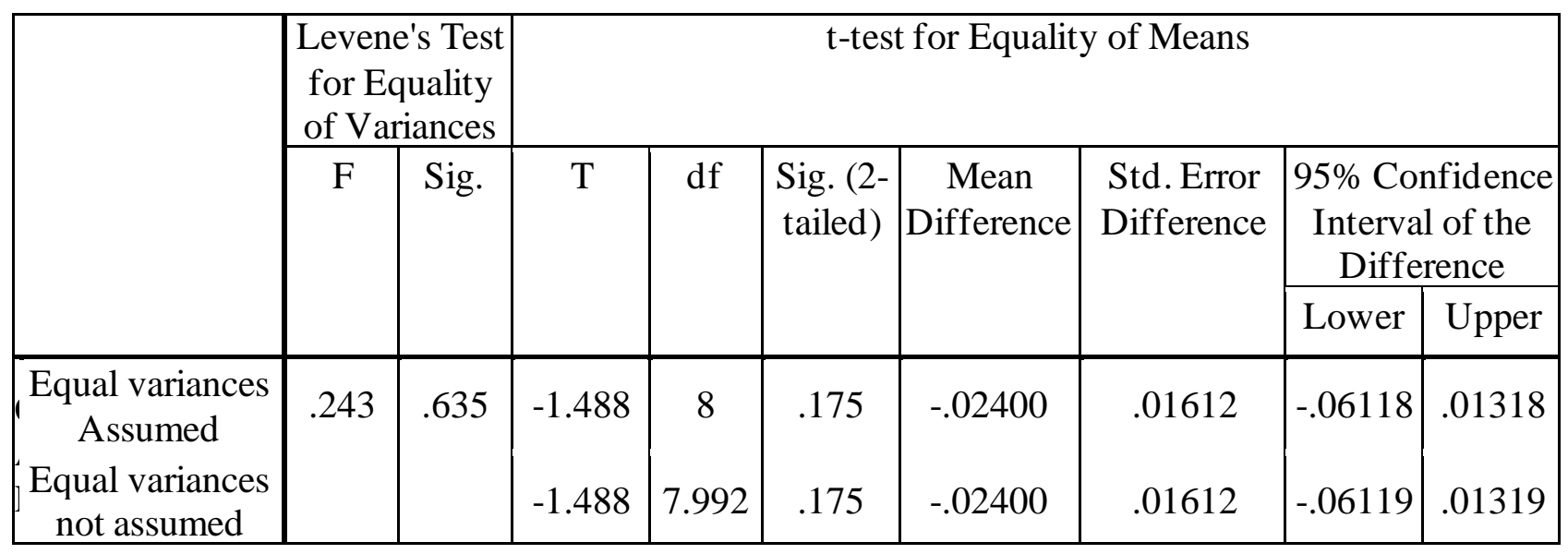

Sumber: Data Olahan, 2019.

Hasil uji independent t-test menunjukkan bahwa nilai Sig. Levene's Test for Equality of Variances adalah sebesar 0,635 >0,05 maka dapat dinyatakan bahwa varians data antara PT Bank BNI Syariah dan PT Bank BNI Konvensional adalah homogen atau sama.

Berdasarkan tabel output "Independent Samples Test" pada bagian "Equal variences as sumed" diketahui nilai Sig. (2-tailed) sebesar 0,175 $>0,05$ dan nilai t-hitung $<\mathrm{t}$-tabel yaitu sebesar 1,488 $<2,306$ maka sebagaimana dasar pengambilan keputusan dalam uji independent sample t-test dapat disimpulkan Ho1 diterima dan Ha1 ditolak. Dengan demikian dapat disimpulkan bahwa tidak ada perbedaan yang signiifikan (nyata) antara rata-rata CAR pada PT Bank BNI Syariah dengan PT Bank BNI Konvensional. 
Tabel 4.2

Independent Samples Test

\begin{tabular}{|c|c|c|c|c|c|c|c|c|c|}
\hline & \multicolumn{2}{|c|}{$\begin{array}{c}\text { Levene's } \\
\text { Test for } \\
\text { Equality of } \\
\text { Variances }\end{array}$} & \multicolumn{7}{|c|}{ t-test for Equality of Means } \\
\hline & \multirow[t]{2}{*}{$\mathrm{F}$} & \multirow[t]{2}{*}{ Sig. } & \multirow[t]{2}{*}{$\mathrm{T}$} & \multirow[t]{2}{*}{$\mathrm{df}$} & \multirow[t]{2}{*}{$\begin{array}{l}\text { Sig. (2- } \\
\text { tailed) }\end{array}$} & \multirow[t]{2}{*}{$\begin{array}{c}\text { Mean } \\
\text { Difference }\end{array}$} & \multirow[t]{2}{*}{$\begin{array}{l}\text { Std. Error } \\
\text { Difference }\end{array}$} & \multicolumn{2}{|c|}{$\begin{array}{l}95 \% \text { Confidence } \\
\text { Interval of the } \\
\text { Difference }\end{array}$} \\
\hline & & & & & & & & Lower & Upper \\
\hline $\begin{array}{l}\text { N Equal variances } \\
\text { PFassumed }\end{array}$ & .236 & .640 & 5.269 & 8 & .001 & .77400 & .14689 & .43526 & 1.11274 \\
\hline $\begin{array}{l}\text { N Equal variances } \\
\text { PLnot assumed }\end{array}$ & & & 5.269 & 7.994 & .001 & .77400 & .14689 & .43522 & 1.11278 \\
\hline
\end{tabular}

Sumber: Data Olahan, 2019.

Hasil uji independent t-test menunjukkan bahwa nilai Sig. Levene's Test for Equality of Variances adalah sebesar 0,640 > 0,05 maka dapat dinyatakan bahwa varians data antara Bank BNI Syariah dan Bank BNI adalah homogen atau sama.

Berdasarkan tabel output "Independent Samples Test" pada bagian "Equal variences assumed" diketahui nilai Sig. (2-tailed) sebesar 0,001<0,05 dan nilai t-hitung $>$ t-tabel yaitu sebesar 5,269 > 2,306 maka sebagaimana dasar pengambilan keputusan dalam uji independent sample t-test dapat disimpulkan $\mathrm{Ho} 2$ ditolak dan $\mathrm{Ha} 2$ diterima. Dengan demikian dapat disimpulkan bahwa ada perbedaan yang signiifikan (nyata) antara rata-rata NPF/NPL pada PT Bank BNI Syariah dengan PT Bank BNI Konvensional. 
Tabel 4.3

Independent Samples Test

\begin{tabular}{|c|c|c|c|c|c|c|c|c|c|}
\hline & \multicolumn{2}{|c|}{$\begin{array}{c}\text { Levene's Test } \\
\text { for Equality } \\
\text { of Variances }\end{array}$} & \multicolumn{7}{|c|}{ t-test for Equality of Means } \\
\hline & \multirow[t]{2}{*}{$\mathrm{F}$} & \multirow[t]{2}{*}{ Sig. } & \multirow[t]{2}{*}{$\mathrm{t}$} & \multirow[t]{2}{*}{ df } & \multirow[t]{2}{*}{$\begin{array}{l}\text { Sig. (2- } \\
\text { tailed) }\end{array}$} & \multirow[t]{2}{*}{$\begin{array}{c}\text { Mean } \\
\text { Difference }\end{array}$} & \multirow[t]{2}{*}{$\begin{array}{l}\text { Std. Error } \\
\text { Difference }\end{array}$} & \multicolumn{2}{|c|}{$\begin{array}{l}95 \% \text { Confidence } \\
\text { Interval of the } \\
\text { Difference }\end{array}$} \\
\hline & & & & & & & & Lower & Upper \\
\hline $\begin{array}{c}\text { Equal } \\
\text { variances } \\
\text { assumed }\end{array}$ & 1.590 & .243 & 10.639 & 8 & .000 & 16.37200 & 1.53884 & 12.82343 & 19.92057 \\
\hline $\begin{array}{c}\text { Equal } \\
\text { variances } \\
\text { not assumed } \\
\end{array}$ & & & 10.639 & 6.661 & .000 & 16.37200 & 1.53884 & 12.69541 & 20.04859 \\
\hline
\end{tabular}

Sumber: Data Olahan, 2019.

Hasil uji independent t-test menunjukkan bahwa nilai Sig. Levene's Test for Equality of Variances adalah sebesar 0,243>0,05 maka dapat dinyatakan bahwa varians data antara Bank BNI Syariah dan Bank BNI adalah homogen atau sama.

Berdasarkan tabel output "Independent Samples Test" pada bagian "Equal variences assumed" diketahui nilai Sig. (2-tailed) sebesar 0,000 $<0,05$ maka sebagaimana dasar pengambilan keputusan dalam uji independent sample t-test dapat disimpulkan Ho3 ditolak dan Ha3 diterima. Dengan demikian dapat disimpulkan bahwa ada perbedaan yang signiifikan (nyata) antara rata-rata BOPO pada PT Bank BNI Syariah dengan PT Bank BNI Konvensional.

Kemudian dari tabel output diatas dapat diketahui bahwa nilai t-hitung lebih besar dari t-tabel yaitu sebesar 10,639 > 2,306 maka dapat disimpulkan Ho3 ditolak dan Ha3 diterima.yang artinya ada perbedaan rata-rata rasio BOPO antara Bank BNI Syariah dengan Bank BNI. 


\section{Tabel 4.4}

Independent Samples Test

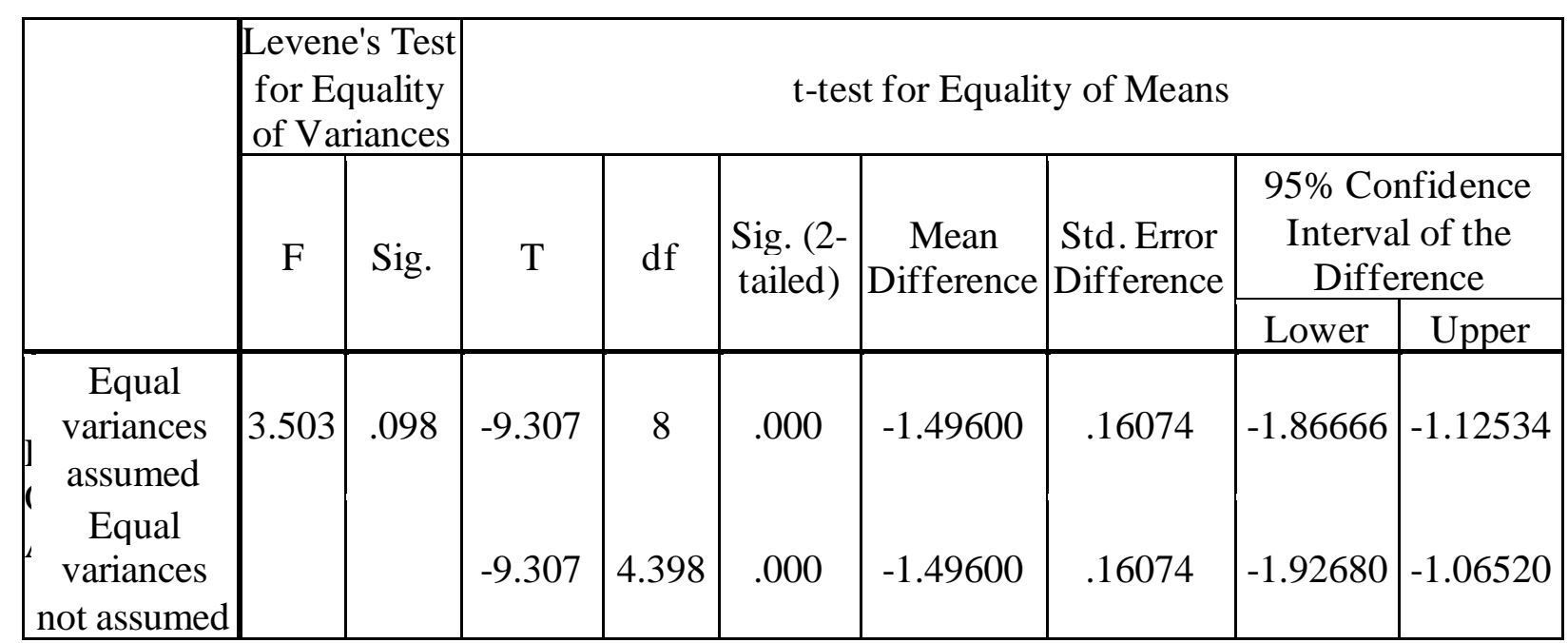

Sumber: Data olahan, 2019.

Hasil uji independent t-test menunjukkan bahwa nilai Sig. Levene's Test for Equality of Variances adalah sebesar 0,098 >0,05 maka dapat dinyatakan bahwa varians data antara Bank BNI Syariah dan Bank BNI adalah homogen atau sama.

Berdasarkan tabel output "Independent Samples Test" pada bagian "Equal variences assumed" diketahui nilai Sig. (2-tailed) sebesar 0,000<0,05 maka sebagaimana dasar pengambilan keputusan dalam uji independent sample t-test dapat disimpulkan Ho4 ditolak dan $\mathrm{Ha} 4$ diterima. Dengan demikian dapat disimpulkan bahwa ada perbedaan yang signiifikan (nyata) antara rata-rata ROA pada Bank BNI Syariah dengan Bank BNI.

Kemudian dari tabel output diatas dapat diketahui bahwa nilai t-hitung lebih besar dari t-tabel yaitu sebesar 9,307 > 2,306 maka dapat disimpulkan Ho4 ditolak dan Ha4 diterima.yang artinya ada perbedaan rata-rata rasio ROA antara Bank BNI Syariah dengan Bank BNI.

Hasil uji independent t-test menunjukkan bahwa nilai Sig. Levene's Test for Equality of Variances adalah sebesar $0,008<0,05$ maka dapat dinyatakan bahwa varians data antara Bank BNI Syariah dan Bank BNI adalah heterogen atau tidak sama. 
Tabel 4.5

Independent Samples Test

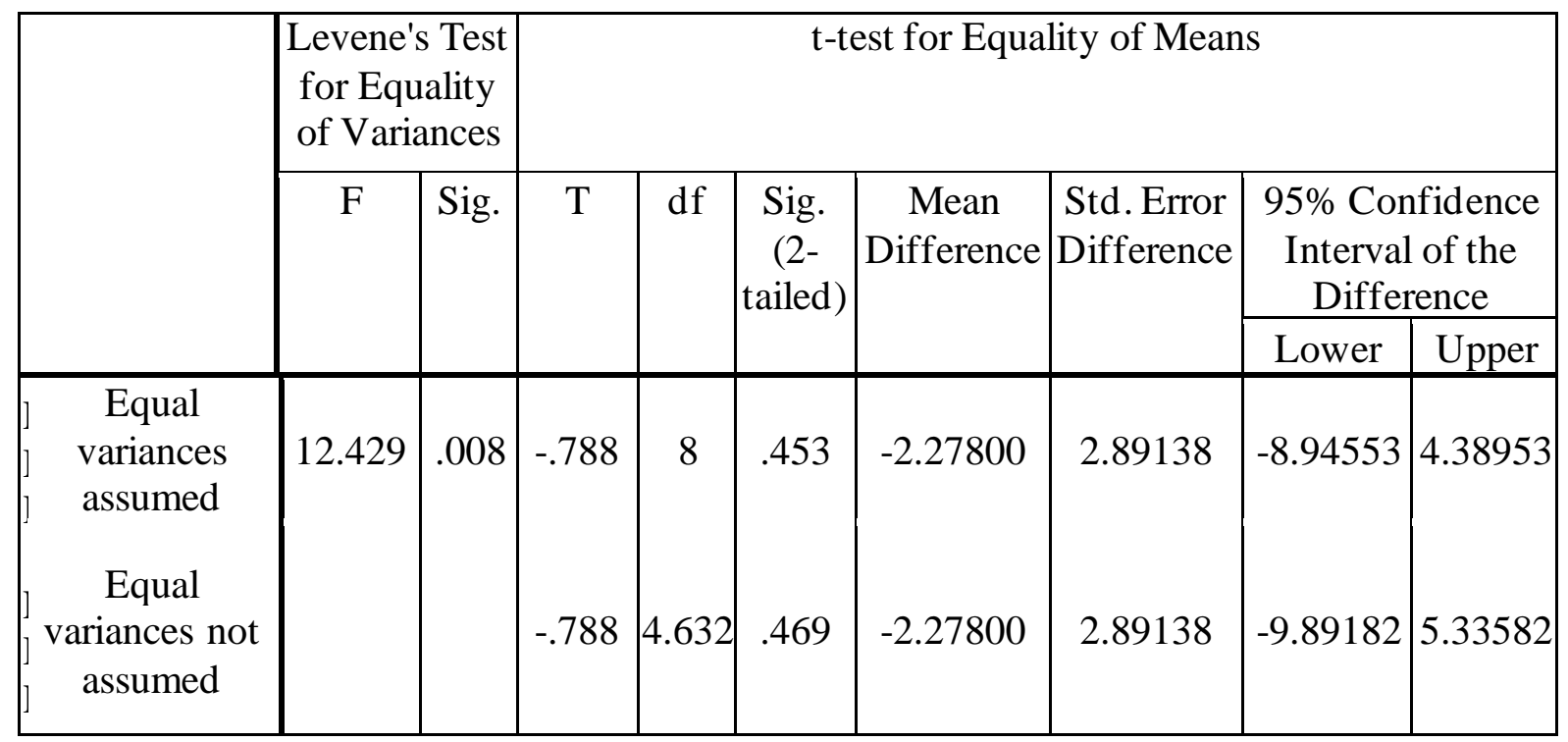

Sumber: Data olahan, 2019.

Berdasarkan tabel output "Independent Samples Test" pada bagian "Equal variences assumed" diketahui nilai Sig. (2-tailed) sebesar 0,453 >0,05 maka sebagaimana dasar pengambilan keputusan dalam uji independent sample t-test dapat disimpulkan Ho5 diterima dan Ha5 ditolak. Dengan demikian dapat disimpulkan bahwa tidak ada perbedaan yang signiifikan (nyata) antara rata-rata FDR/LDR pada PT Bank BNI Syariah dengan PT Bank BNI Konvensional.

Kemudian dari tabel output diatas dapat diketahui bahwa nilai t-hitung < dari ttabel yaitu sebesar 0,788 $<2,306$ maka dapat disimpulkan Ho5 diterima dan Ha5 ditolak yang artinya tidak ada perbedaan rata-rata rasio FDR/LDR antara Bank BNI Syariah dengan Bank BNI.

\section{KESIMPULAN}

Berdasarkan hasil analisis data dan pembahasan yang telah dikemukakan diatas dapat diambil kesimpulan sebagai berikut:

a. Tidak ada perbedaan yang signifikan antara rata-rata CAR pada PT Bank BNI Syariah dengan PT Bank BNI Konvensional. 
b. Ada perbedaan yang signifikan antara rata-rata NPF/NPL pada PT Bank BNI Syariah dengan PT Bank BNI Konvensional.

c. Ada perbedaan yang signifikan pada rata-rata rasio BOPO antara Bank BNI Syariah dengan Bank BNI Konvensional.

d. Ada perbedaan yang signifikan pada rata-rata rasio ROA antara Bank BNI Syariah dengan Bank BNI Konvensional.

e. Tidak ada perbedaan yang signifikan pada rata-rata rasio FDR/LDR antara Bank BNI Syariah dengan Bank BNI Konvensional.

\section{DAFTAR PUSTAKA}

Budisantoso, Totok dan Triandaru Sigit. 2006. Bank dan Lembaga Keuangan Lain. Jakarta

Salemba Empat.

Dendawijaya, Lukman. 2009. Manajemen Perbankan. Jakarta: Ghalia Indonesia.

Hermawati, Tria, et al. 2018. Analisis Perbandingan Kinerja Keuangan Bank Konvensional dan Bank Syariah pada PT Bank Mandiri dan PT Bank Syariah Mandiri dengan Menggunakan Metode Camel. Universitas Islam Bandung Prosiding Akuntansi 4 (2), 734-740.

http://www.bi.go.id/web/id/

http://www.ojk.go.id/web/id/

https://www.bni.co.id/id-id/

https://www.bnisyariah.co.id/

Ismail. 2009. Akuntansi Bank Teori dan Aplikasi. Jakarta: Kencana.

Jacob, Jeremiah K.D. 2013. Analisis Metode Laporan Keuangan dengan Metode CAMEL

untuk Menilai Tingkat Kesehatan Perbankan. Jurnal EMBA ISSN 2303-1174 Vol.1 No.3.

Jahja, Adi Susilo, et al. 2012. Analisis Perbandingan Kinerja Keuangan Perbankan Syariah dengan Perbankan Konvensional. Episteme 7 (2). 337-360.

Jumingan. 2011. Analisis Laporan Keuangan. Jakarta: PT.Bumi Aksara. 
Kasmir. 2003. Analisis Laporan Keuagan. Jakarta: Raja Grafindo Persada.

Kuncoro, Mudrajad dan Suhardjono. 2002. Manajemen Perbankan. Yogyakarta: BPFE.

Muhammad. 2005. Manajemen Bank Syariah. Yogyakarta : UPP AMP YKPN

Pasrizal, Himyar, et al. 2018. Perbandingan Kinerja Keuangan Bank Umum Syariah dan Bank Umum Konvensional di Indonesia pada Periode 2011-2016. Batusangkar International Conference III (15-16). 131-142.

Sudarsono, Heri. 2013. Bank dan Lembaga Keuangan Syariah. Ekonisia

Syafi'I Antonio, Muhammad, 2001. Bank Syariah dari Teori Ke Praktik. Gema Insani Press, Jakarta, 2001 